\title{
World Systems Theory, Core Periphery Interactions and Elite Economic Exchange in Mississippian Societies
}

\author{
Robert J.Jeske \\ Department of Anthropology \\ Indiana-Purdue University \\ Fort Wayne, IN 46805 \\ jeske@cvax.ipfw.indiana.edu
}

Copyright 1996 by Robert J.Jeske. Please do not cite without permission of the author.

\section{v. $7 / 8 / 96$}

\begin{abstract}
World Systems Theory has been one approach used to explain the rise of the Mississippian social and political phenomenon. In this paper it is argued that a hierarchical model of core- periphery interaction does not explain the Cahokian phenomenon, because several crucial elements of such a model cannot be demonstrated to have existed within the Mississippian system. It is suggested that looking at Mississippian society as a differential core-peripheral system may have utility as a framework for including concepts such as gateway communities and interaction spheres previously used to describe the economic interactions between Cahokia and its neighbors.
\end{abstract}

\section{Introduction}

Archaeologists have long sought an explanation for the rise of Mississippian society in the major river valleys of the American Midwest and Southeast between A.D. 1000 and 1500 (Smith 1978). Over the years, our explanations have changed with the changing fashions of then-current theories of cultural evolution. From diffusion to cultural ecology to economic models of redistributive exchange, we have attempted to put a finger on the causal variables involved in the production of certain ceramic wares, the construction of earthen platform mounds, and the large and highly organized residential and ritual sites of these people.

[Page 1]

Journal of World-Systems Research

None of these models have proven completely satisfactory, failing at one level or another to account for the complexity of Mississippian intergroup interactions revealed by the 
archaeological record. With the emergence of World Systems Theory (WST) (Wallerstein 1974) within the anthropological community, it is only natural that archaeologists should attempt to use it as a way to gain some insight into this longstanding archacological problem (cf. Peregrine 1991). In this study, I will attempt a critical examination of WST as it might pertain to Mississippian society. A brief review of what we know about Mississippian social and political economy is necessary before we explore how well WST works to explain what we see in the Midwest and Southeast United States between AD 1000 and 1500.

\section{Traditional View of Mississippian Social-Political Economy}

Middle Mississippian is a term used to describe an archaeological culture that flourished in the major river systems of the midwest and southeast United States between A.D. 1000 and A.D. 1500 (Figure 1). Middle Mississippian society is traditionally viewed as a ranked level society (Phillips and Brown 1978). The social system is seen as pyramidal, with ruling elites at the top, a mid-level grouping of semi-elites and a larger population of non-elites. Data for this demographic make-up are provided by studies (e.g., Peebles and Kus [1977]) that have demonstrated a correlation of grave goods and health indicators with spatial location in cemeteries. In addition, the distribution of exotic or non-local artifacts in graves is usually skewed towards males, and there may be a correlation of materials within genetically related clusters of individuals. 


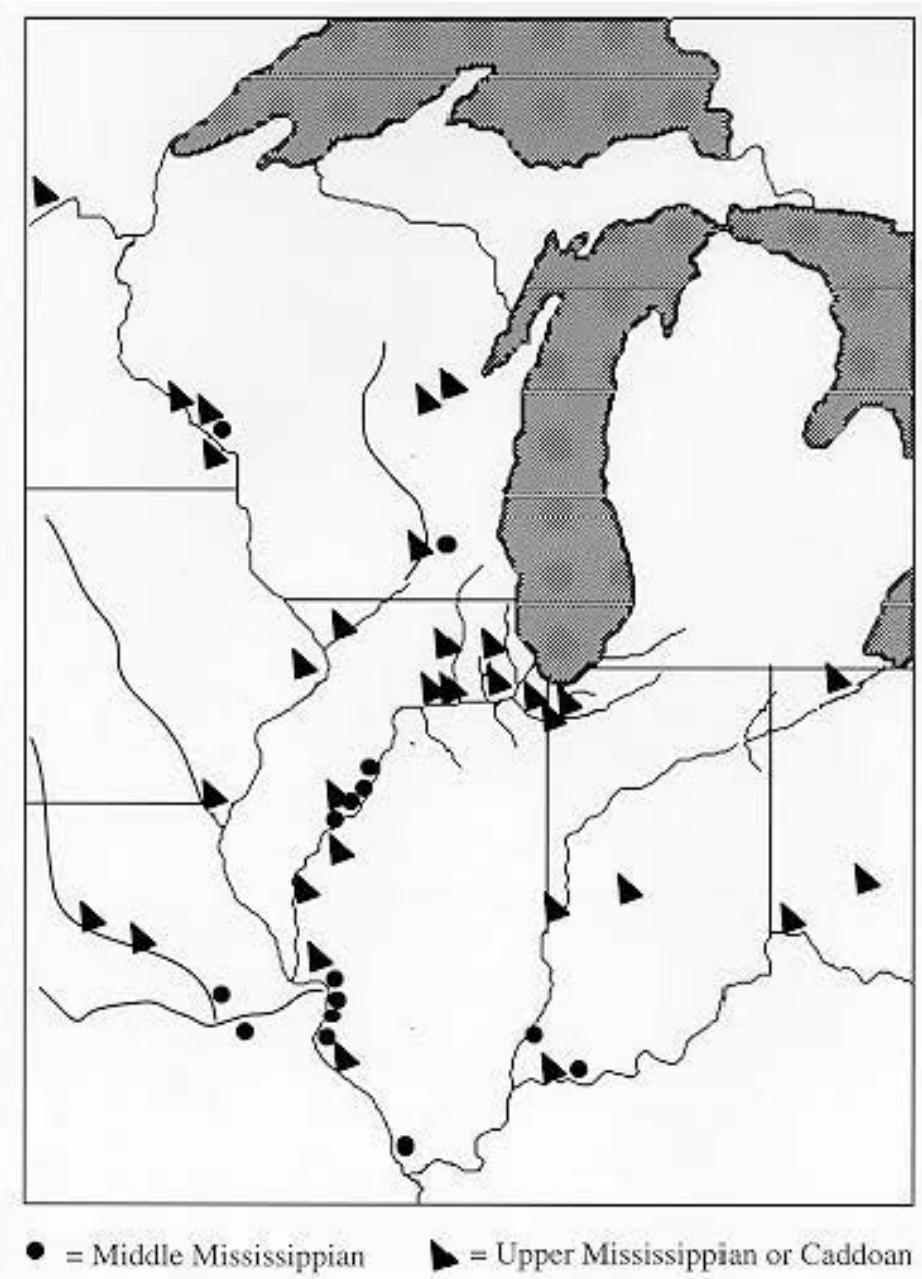

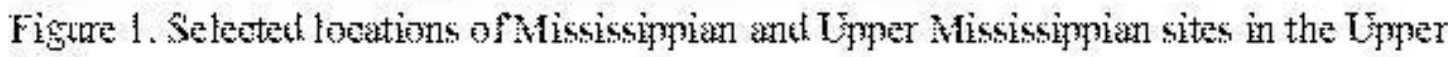
Mikvest

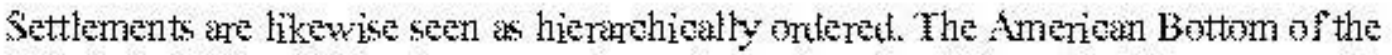
Mississingi River Valley is seen as the arehetypal setting (Figrore 2): Six-square mileCahokia, with its giant Aonk's Momk and some 120 other mownes is onsikerel the entral place or first-line ommonity; strowned by smatler, but still impressinely large

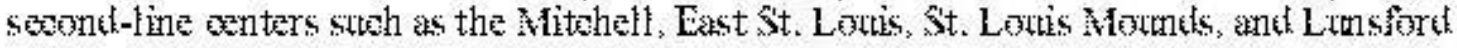
Pilcher sites; which are in trun the foed points for smaller single-mernd thint-line sites; arewend which oluster

\section{[Page 2]}

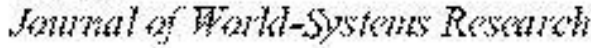

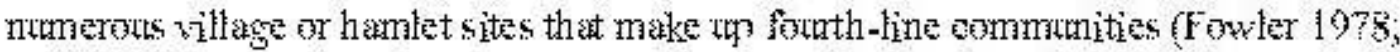
Fall 1991). In the Ameriean Battoms and staromkling refions, these hamlets typieally 


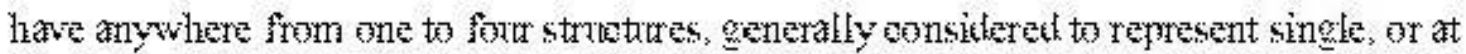
the most, a few related howtsehwelds (Melyer and Collins 1995; Kogers 1995), while in the sortheast, the number of struetures at the base-line commonity arpears to be somewhat higher (Stlliwan $19 \% 5)$.

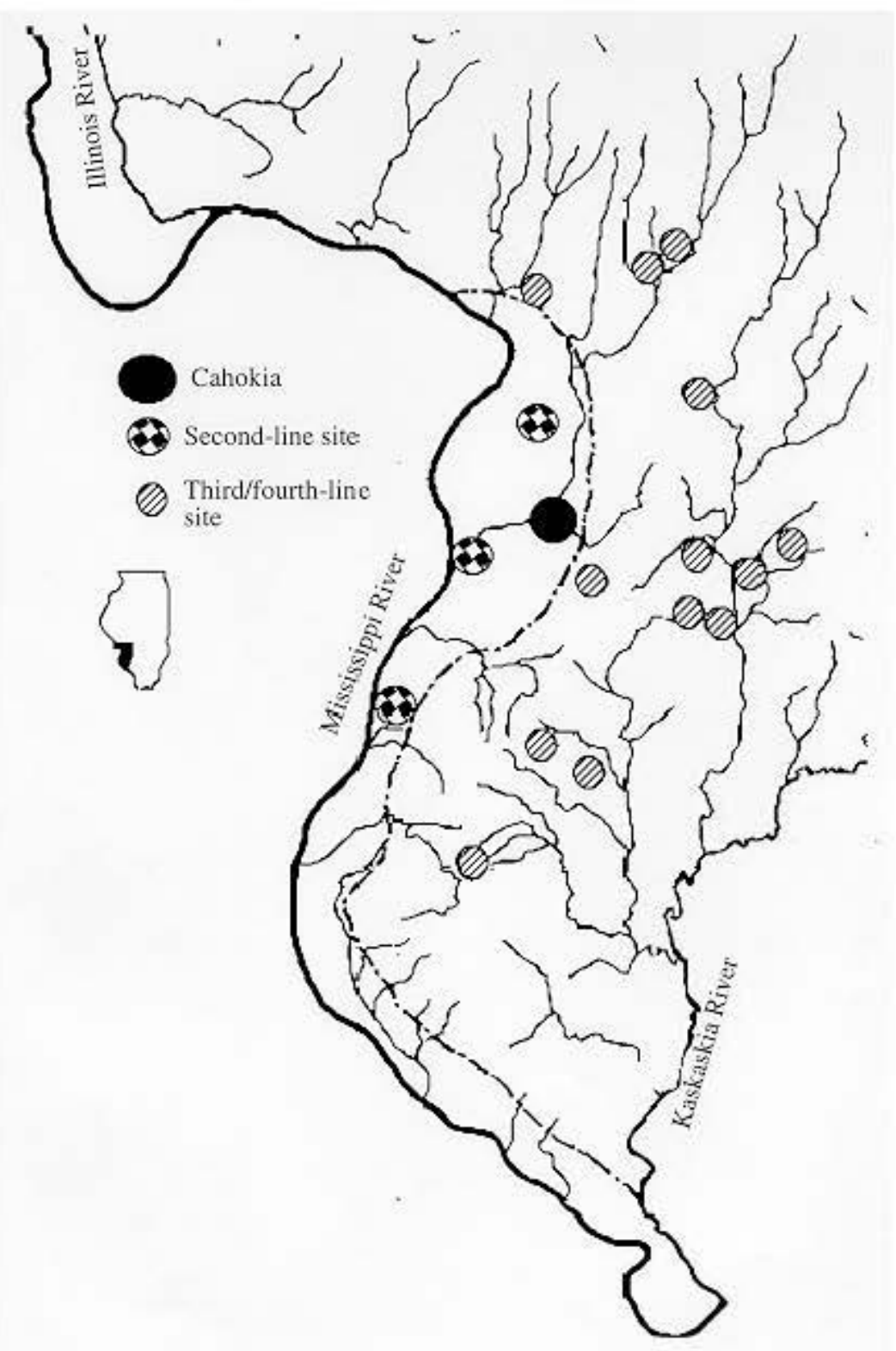

Figne 2. Amerien bottom Core Area.

The stosistene eomomy is generally tepieted a a maize ( $Z$ on bays) and sptash

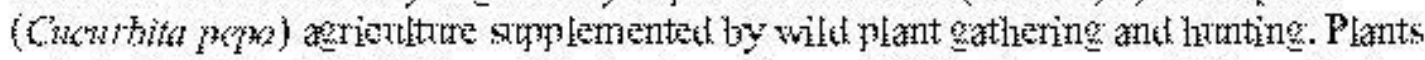

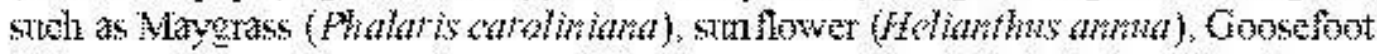

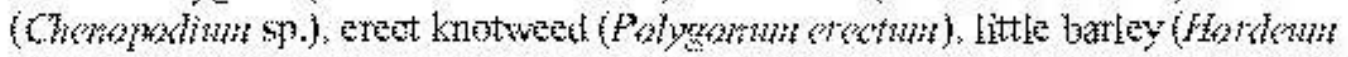
ynyilhum) and berries (e.g. Wawiminn sp.) were all part of the Mississimpian thet. Beans 
(Phaseolus sp.) are a later introduction in some areas of the Mississippian world, but are not found in the American Bottom. Tobacco (Nicotania rustica) was grown for ritual or recreational purposes (Parker 1987). While irrigation was not used, at least some fields were improved through the use of a raised field technique to aid in drainage and frost protection (Riley 1993). Aside from the dog (Canis familiaris), no animals are known to have been domesticated.

There is biological and archacological evidence for warfare. In addition to skeletons bearing evidence of violent death (Milner et al. 1991), some Mississippian sites are stockaded (Goldstein and Richards 1991), and there are symbolic representations of pottery and shell engravings, suggesting that a warrior class or at least some form of warrior veneration existed (Phillips and Brown 1978). The archaeological evidence is supported by ethnohistoric data from southeastern groups such as the Natchez, who were following this basic pattern at the time of European intrusion (Steponaitis 1978). The ethnohistoric data do give the impression that high-level elites at larger sites exerted influence, if not control, on individuals at other locations. However, none of the historically known groups approach a state-level of social and political complexity. In particular, complex bureaucracies with the power to coerce taxation and draft an army were not features of the social and political structures of these groups. It is still a matter of debate whether the Mississippian world of 200-400 years earlier contained an incipient state-level sociopolitical system.

[Page 3]

Journal of World-Systems Research

\section{World Systems Theory and Mississippian}

As defined by Wallerstein, the world systems perspective emphasizes the asymmetrical political and economic exchange between a highly developed core and a lesser developed periphery. The core is highly developed both economically and politically, with centralized authorities supporting an exchange system that encourages the accumulation and investment of surplus (Stein 1993). These elites control the flow of goods between the core and periphery through colonial administration or control of local elites, who are dependent upon core elites for their own power. The periphery provides a flow of staple goods and raw materials to the core in exchange for value-added or finished commodities.

A number of scholars (e.g., Chase-Dunn and Hall 1991; Schneider 1991) have argued that Wallerstein's initial formulation of WST, designed to explain a European capitalist environment, is probably inadequate for non-state societies. For one thing, Wallerstein's view assumes that there is inequality inherent in the core-periphery exchange, but Chase- 
Dunn and Hall would like to see WST account for those situations where exchange inequities are not readily apparent. In order to provide for a more flexible approach, Chase-Dunn and Hall offer a typology of possible world systems forms covering sociopolitical-economic situations from band-level, kin-based lineage systems to fully industrialized state-level capitalist systems. To denote the more generalized approach, they favor the use of the term core-periphery or even more generically, intersocietal interactions, rather than Wallerstein's world systems. Their eclectic approach to world systems allows one to operationalize expectations for what a world system would look like on a case by case basis. Again, in order to be flexible enough to encompass as much variation as possible under the rubric of core-periphery, they break core-periphery interactions into two larger groups: core-periphery differentiation, where a large group interacts with a smaller group; and core-periphery hierarchy, where the core demonstrably dominates the smaller group economically, militarily, politically, or ideologically.

Based on the previous discussion of what we think we know of Mississippian society, our case study here falls under Chase-Dunn and Hall's taxon of chiefdom--a non-state, but stratified society. There is probably little controversy on this point, but we need to determine whether the interactions between Cahokia and surrounding smaller polities was

[Page 4]

Journal of World-Systems Research

hierarchical or differential in nature.

In a hierarchical system, the core creates the periphery by pulling it into the exchange system as a politically and economically dependent area (Stein 1993). This creation of a dependent area implies some form of coercive power over the peripheral area, either through military threat or some enticement so powerful that the population in the targeted area accepts their subservient role in the exchange system. In effect, the core must extend to the periphery an offer that they cannot refuse.

Stein suggests that a hierarchical system requires three basic assumptions about the relationships between the core and periphery. First, there must be a fundamental power asymmetry such that the core can dominate the periphery. Second, the model assumes that as a result of this power asymmetry, the core can control an exchange system crucial to its existence. Third, this exchange system must structure all other aspects of the economy in the peripheral society. In the particular case presented here, we envision a chiefdom level society, with a small cadre of ruling elites based in Cahokia who have political, economic, and marriage alliances with each other as well as with elites in outlying areas of the American Bottom and beyond. For a hierarchical model of coreperiphery relations to work, we need to show that the core elites had the capability to coerce other elites, as well as non-elites, into an unequal system of economic exchange. Such coercive power could conceivably consist of military, economic, or ideological 
control of access to desired and/or necessary resources. We can examine Mississippian social relations at Cahokia to see if our example meets these three criteria for a hierarchical core-periphery relationship.

\section{World Systems Theory and Mississippian: Does it Fit?}

When placing Mississippian culture into the taxon of core-periphery interaction, the problem of area bounding (i.e., the geographical extent of the system) is immediately apparent. The problem of bounding core/periphery hierarchies has been di scussed by Chase-Dunn and Hall (1991) and the problem is a significant one in our particular case study. Cahokia and its immediate environs are clearly unique and represent a core area. But the extent of the core, and the further extent of the periphery are much less definite.

The distribution of Middle Mississippian sites in the Midwest shows that, outside of

[Page 5]

Journal of World-Systems Research

Cahokia and the American Bottom, the lower Mississippi, the central Illinois, the lower Wabash, and the Ohio rivers all contain major habitations, suggesting a large scale, farflung geographic extension of Mississippian political and economic hegemony (Figure 1). It is not entirely clear, however, that the entire American Bottom would qualify as a core. It may be that Cahokia and its immediate suburbs were a core, with the American Bottom region a semi-periphery and the sites in the Illinois, Wabash, and Ohio river valleys the periphery. However, it may also be that the entire American Bottom is the core. If Cahokia and the American Bottom is the core, where are the semi-periphery and periphery? The semi-periphery and periphery might well include those sites in the river valleys just mentioned. Major sites in this periphery or semi-periphery include the Angel Site in Indiana (Black 1967), and Dickson Mounds in the Central alllinois river valley (Harn 1980). There is also the Caddoan area of Oklahoma and Arkansas, in particular the Spiro site (Brown et al. 1978). Caddoan sites share many Mississippian traits, yet retain a regionalization that suggests they might be part of a Middle Mississippian periphery, or again, at least semi-periphery. As a further wrinkle, there is a much larger extension of Mississippian into the north, east, and west, which archaeologists have termed Upper Mississippian. Sometimes referred to as Cahokia's Hinterlands (cf. Emerson and Lewis 1978; Mehrer and Collins 1995), it is quite possible that groups in these areas made up the true periphery of the Mississippian world. These are groups whose pottery shares many of the same motifs as Middle Mississippian, but who live at sites which are more similar to Late Woodland villages than to the hierarchical Middle Mississippian hamlet/town/city pattern, and which lack pyramidal mounds. Oneota and Langford are variants of this Upper Mississippian cultural phenomenon found in northern Illinois, northwestern Indiana, Wisconsin, Iowa and Minnesota. These groups were generally less 
dependent upon maize and more involved in a mixed economy of hunting -gathering and maize horticulture (Brown 1982, 1990; Jeske 1990; Pollack and Henderson 1992). Fort Ancient was a southern variant of Upper Mississippian found in central Indiana and Ohio. The Fort Ancient subsistence regime may have been somewhat different from that of Oneota and Langford, including a significantly greater reliance on maize agriculture, and later inclusion of beans, in the diet (Pollack and Henderson 1992; Watson 1988).

Of special interest is the site of Aztalan in southeastern Wisconsin (Goldstein and Richards 1991). This site is a seemingly Middle Mississippian settlement separated from the core by $500 \mathrm{~km}$ and surrounded by several different variants of Upper Mississippian and Late Woodland cultures. The site contains a platform mound and exh ibits evidence for hostilities with its immediate neighbors. Aztalan has sometimes been considered either a colony of

[Page 6]

Journal of World-Systems Research

Cahokia or a trading center between Cahokia and its northern periphery (Barrett 1933; Gibbon 1974; Griffin 1960). Others (Fowler and Hall 1978) have suggested that Aztalan is not representative of direct Cahokian contact, but is a "hybrid resulting from interaction between Middle Mississippian and [local Woodland cultures]" (Hurley 1975, cited in Goldstein and Richards 1991). In a recent study, Goldstein and Richards (1991:206) assert that the site is an example of direct Cahokian contact, although the reasons for the contact are unclear. The site is located on the Crawfish River, which they argue places it in geographic context for movement of trade goods. However, there is no evidence for trade goods flowing through the site, and there are demonstrably many more strategic areas in the north if the Cahokians wished to place a settlement for the control of trade goods from the Great Lakes region to the American Bottoms.

In fact, it appears that we may have a nested core/periphery phenomenon (Chase -Dunn and Hall 1991), with Middle Mississippian American Bottom sites, Middle Mississippian Central Illinois-Wabash-Ohio Rivers sites, Caddoan sites in Arkansas, and Oneota-Fort Ancient-Langford sites of Iowa, Minnesota, Wisconsin, northern Illinois, central Indiana, and Ohio all displaying varying degrees of peripheralization from the central place of Cahokia. Finally, there are hundreds of Mississippian sites on major waterways of the southeastern United States, many of them large regional centers containing platform mounds, plazas and organized residential centers (Smith 1978). However, it is reasonable to assume that Mississippian was a multicentral phenomenon (Chase-Dunn and Hall 1991), and for the purposes of this study, I will treat these southeastern sites as independent and separate socio-political units that had their own core-periphery interactions outside of any connections with Cahokia and the Midwestern Middle Mississippian sites. We do know that this is not entirely true; sea shells from the Gulf Coast are found at Midwestern Mississippian sites. There was some interaction between 
Cahokia and at least some groups to the south, although direct contact between Cahokia and Mississippian sites outside of the Mississippi Valley proper is not definite.

Even if we ignore those "other Mississippians", taking a world systems view of Midwestern Mississippian society is problematic, but teasingly plausible. Looking at Stein's first assertion about hierarchical systems assumptions, we must posit that the American Bottom area possessed a power asymmetry with its periphery. Judging by the size and complexity of Cahokia and its associated suburbs, a strong argument can be made that it certainly had a huge population relative to other inhabited areas in the American Bottom.

[Page 7]

Journal of World-Systems Research

The population numbers suggest that the Cahokia elite commanded significant potential power, assuming that institutions capable of organizing that population into active coordinated labor existed. The building of Monk's Mound, containing 22 million cubic feet of earth, suggests that Cahokia's elite did possess the ability to organize large scale labor intensive activities. It is not unreasonable to suggest that Cahokia possessed the potential for an asymmetrical power relationship with its assumed periphery and semiperiphery. Cahokia itself could plausibly have controlled the American Bottom as part of its core.

But we also have to contend with the notion of power distance decay (Stein 1993). That is, how far can a core polity extend coercive power over peripheral areas? The short answer for Cahokia may be: "Not Far". Ross Hassig (1992) has shown that the ability of the state-level Aztecs to throw their military weight around was bounded fairly tightly. The Aztecs had difficulties with groups as close as the Chichimees, and did not have the ability to take on easily the Maya city states of the Yucatan. To expect the Cahokians, who did not have nearly the population or social integration of the Aztecs, to defeat groups militarily in Minnesota, Ohio, Iowa, and Wisconsin stretches credulity.

Evidence for the degree and evolution of social integration at Cahokia and its environs is provided by Mehrer and Collins (1995). Based on excavations at the ICT -II tract at Cahokia, they show that during the Lohman Phase (AD 1100-1150) the residential community plan was highly structured and oriented on a central grid system, indicating a high level of community control by a central power. Centralized authority is perhaps best symbolized by the dramatic burials within Mound 72, where an aged male was laid out on a cloak of shell beads; several individuals buried alongside him are interpreted as sacrificed attendants. Four young males between the ages of 18 and 25, who were buried minus their heads and hands, with arms interlinked, are interpreted as an 'honor guard'. Also nearby, an ossuary contained the remains of 33 young women, interpreted also as sacrifices. It is conceivable that the aged individual buried with such ceremony, or 
someone like him, was a central authority capable of organizing the growth of the large ceremonial and residential site of Cahokia along a well-defined grid system.

At this time, population was expanding rapidly, and the "mound and town" centers characterizing the Mississippian settlement pattern in the American Bottom first appear. In the hinterlands (for Mehrer and Collins, the American Bottom excluding Cahokia's immediate environs), the Late Woodland settlement pattern of large villages is replaced by the hierarchical system with individual households or farmsteads as the base unit. Political and

[Page 8]

Journal of World-Systems Research

social control became centralized at this time as individuals left villages and moved into larger towns or smaller hamlets (Mehrer and Collins 1995:43). By the Stirling Phase (AD 1150-1200), however, with Cahokia's population at its maximum, the socio-political system already seemed to be segmenting. The same ICT -II tract at Cahokia shows that structures were no longer oriented on a central grid, and the residential area was separated from the central plaza and mound area of the site by stockade walls. More importantly, local residences were structured around their own mound and plaza complexes. Outside of Cahokia proper, differentiation of individual structures within farmsteads indicates local stratification. In sum, it appears that local communities were oriented to local elites rather than to a centralized authority (Mehrer and Collins 1995:47). As Cahokia and the American Bottom population declined through the following Moorehead and Sand Prairie Phases, it appears that local elite control continued at the household level, rather than as a centrally based system (Mehrer and Collins:57).

Even if we discount the direct authoritarian control by a single or small group of elites over the entire population, it is conceivable that Cahokia, because of its sheer size and magnitude relative to neighboring Mississippian groups, might have been perceived as a credible military threat to far off groups. Core elites may well have been able to enlist or coerce significant military support through political/economic/marriage ties with local elites. Manpower necessary for significant military activity is readily available to elites in ethnographically known chiefdom-level societies--especially at the level of raiding (Keeley 1996). Warfare as persistent raiding is a pattern seen among non-state societies in the historic record. Historic Iroquois extended terroristic raiding parties far into the Illinois Country, for example, destroying the Grand Village of the Kaskaskia in the Upper Illinois River Valley in 1680 (Brown 1961). The Miami, based in northern Indiana, maintained a long-standing blood feud with the Chickasaw of Georgia during the 18th century (Callender 1978).

Archaeological data suggest that Cahokians could conceiva bly have used intimidation through intermittent raiding as a coercive tactic. Data from mortality profiles and skeletal 
pathologies at a peripheral Oneota site in the Central Illinois River Valley (Norris Farms \#36) dating to the 13th and 14th centuries suggest that long-term, intermittent, smallscale raiding resulted in a high rate of homicides among adults (Milner et al. 1991). The site is contemporaneous with both Middle Mississippian sites and other Oneota sites in the Central Illinois Valley. Evidence for significant violence is also present on skeletons from the Fisher site, on the Kankakee River near Joliet, Illinois (Langford 1927). The Fisher site is a Langford and Oneota site, also occupied during the 13th and 14th centuries. Decapitated

[Page 9]

Journal of World-Systems Research

skulls and other evidence for violence were also recently recovered from the Tremaine site, a 14th century Oneota occupation in the Mississippi River valley in west-central Wisconsin (Eric Hollinger, personal communication). While it is not known who their antagonists were, there is no doubt that raiding and warfare was a significant aspect of life in the Cahokia periphery and semi-periphery. Such violence can be seen as evidence of intergroup coercion.

Stein's second assumption, that because of this power asymmetry, the core elite were able to control trade, is much more difficult to ascertain. There is little evidence that peripheral areas were trading anything of economic importance to Cahokia. There is no direct evidence that American Bottom populations needed anything from the north and northwest.

The organization of settlements in the American Bottom strongly suggests that the population within the region itself was deployed in a manner that insured adequate agricultural production if we posit institutionalized redistribution of resources (Kelley 1978). Sites are located on the floodplain, terrace, and uplands in a way that minimizes risk from either flooding or drought. Potential failure in one portion of the region could be made up by redistributing surpluses from another. Control of this redistribution has been argued by some to account for the rise of Cahokia and its elite (Fowler 1969). The need for redistribution of resources within the American Bottom, however, does open up the possibility that at least some agricultural produce may have been sent from the semiperiphery to the core area and rechanneled. It is also possible that dried bison meat may have been sent to Cahokia from peripheral sites. While such meat would be archaeologically invisible at Cahokia, bison kills indicative of more than local-scale consumption at peripheral sites would not be. A systematic investigation of Mississippian era bison kill sites on the plains with this hypothesis in mind might be in order.

In addition, faunal remains at Oneota residential sites in the Midwest suggest that it is possible that meat may have been traded to Cahokia. Kuznar (1994), in an ethnoarchaeological study of Andean herding communities, has demonstrated that faunal assemblages from sites of pastoralists who trade meat to agriculturalists show a "charqui 
effect". Charqui is dried meat sent to agriculturalists by pastoral producers. The production of charqui at pastoral sites yields a faunal assemblage that is he avily biased towards heads and lower limb bones. Animal portions associated with high meat:bone ratio are shipped; the low meat:bone ratio parts are retained at the pastoral sites for local consumption. A brief survey of the faunal remains reported from Upper Mississippian sites suggests that the charqui effect may have operated at some of these sites. Although Upper Mississippian groups are

[Page 10]

Journal of World-Systems Research

characterized as having a general subsistence economy (Brown 1982; Jesk e 1990; Michalik 1982), and several data sets support this assertion (Breitburg 1992; Yerkes 1985), several site reports from Upper Mississippian sites in Wisconsin and northern Illinois indicate a bias towards heads and lower limb portions in faunal assemblages (Neusius 1990; Styles and White 1993). However, the situation is far from clear, and a larger, more formal review of this evidence is suggested for future research.

Moreover, there is no evidence that Cahokians needed or desired dried meat. The fact that Cahokians did not grow beans, an important supplier of amino acids in a protein-poor maize-base diet, suggests that they had other protein sources, such as meat. Unfortunately, whether the protein source was locally hunted game or was imported as dried meat is not known, but it seems likely that a protein-stressed population would supplement a meat-poor diet with as many alternatives as possible.

An alternative economic commodity that may have been sent from the periphery to the core is slaves. Like dried meat, slave trading would be largely invisible in the archaeological record. Unlike bison hunting, there would be no local production areas present in the periphery. Although it would be very difficult to see slave trading archaeologically, there is also very little ethnohistoric evidence that indicates clearly that slaves were an integral part of the Mississippian and historic Native American economy. War captives often became slaves, but active, large scale trade in slaves is not recorded for Midwestern or southeastern groups (Ritzenthaler and Ritzenthaler 1991; Snow 1995; Swanton 1946; Trigger 1990). It is not likely that slaving was an important, widespread, or frequent economic exchange between periphery and core.

Although Wallerstein was insistent that economically important goods are prime actors in core periphery interactions, Schneider (1991) and others have since argued that exchange in elite-controlled ritual paraphernalia may be more important than staples, especially in pre-capitalist economies. Peregrine (1991) has argued that trade in exotic or prestige goods was crucial for the evolution of Mississippian social complexity. He contends that control of exotic and prestige goods necessary for 'social reproduction' by elite males provided an impetus for competition and eventual elaboration of the social system. Peregrine's argument is that the distribution of exotic goods does not reflect pure 
economic exchange or competition for material resources, but is actually a reflection of individual males' desire for greater prestige and acceptance into an elite hierarchy. Although he refers to his model as a

[Page 11]

Journal of World-Systems Research

world systems approach, Peregrine actually harkens back to older models of kinship based exchange as a basis for social complexity (Malinowski 1922; Rosman and Rubel 1971; Strathern 1971). Although Peregrine does not broach the topic, the power-prestige approach may also be used in a sociobiological context, in which males who garner status through economically non-optimal but risky activities have increased access to women, enhancing their ability to reproduce themselves biologically (Chagnon 1988; Hawkes 1994).

In an attempt to show that Mississippian exchange was not centered around economic necessity, but was structured by elite power-prestige ties, Peregrine (1991) puts forth three major hypotheses: that core sites should have more exotic and prestige goods than peripheral sites, that adult males should control exotic and prestige goods and be buried with more of these items than others, and that goods should be directed by adult males to particular people or places. He tests his hypotheses by examining the distribution of shell bead artifacts, "exotic goods" (shell beads plus selected artifacts found in burials), and "prestige goods" (selected artifacts minus shell beads), in burials at four sites in the American Bottom and two sites in the Little Tennessee River area (Peregrine 1991:73). Unfortunately, the data at his disposal are inadequate to answer hypotheses one and three, so he uses his data from the six sites to test them indirectly. Despite Peregrine's best efforts, most of his tests are statistically insignificant, leaving his hypotheses unsupported by the archaeological record.

If the data do not allow one to demonstrate that elites controlled trade using Peregrine's example, is it possible at least to discuss the distribution of trade items in the Midwest? In fact, there is evidence that certain classes of exotic or ritual-associated artifacts were exported from Cahokia to the north and northwest. In particular, Ramey Incised Pottery (Figure 3), long-nosed god masquettes, and marine shell ornaments seem to be associated strongly with a Cahokian influence or presence on sites in the semi-periphery and periphery (Hall 1991). Trade in these exotic or ritual items can be seen as elites from Cahokia cementing relationships with local elites in the periphery, or alternatively, these items reflect colonial administrators in the periphery. 


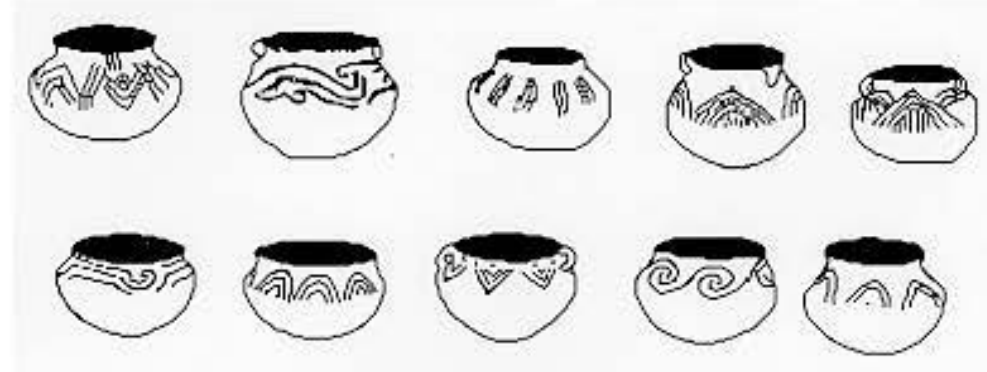

Figrue 3. Top Row: Variants of Onesta Poutery

Bottom Row: Variants of Ramey Ineised Pattery

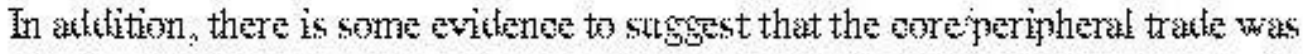
asymmetrieal in that some ritual items seem to be sent to the periphery, with little retum to the wore. John Kelley (1991) notes that when we examine the tistribution of exotic antifaets in Cahokia and its northern periphery. we see that trate items mate from materials to the south of Cahokia are forme at Cahokia and its northern periyhery. These atifacts indelute marine shals and hoes mate from a partientar, highly loealizad material aded Mill Creek

[Page 1.2]

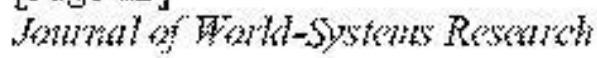

Chert. lowever, nothern antifads are not forme to the south of Cahokia. To Kelley, this pattern strgests that the Ameriean Bottom angpears to be a ondtrit, or gateway oommutuity for the movement of seuthern goeds such as marine shell northwark. Kelley strgesest that the Cahokia development begins as an outpost on the northem edge of a southern oore areas, and eventually is elaborated through its fonetion as a gateway for the movements of these ritual items. However, his view begs the ntatestion, what is being returned to the southem oore? If most everything is flowing in one thedtom, there is no trate; there is thistribution without eonnomie ontext.

Some northern trake items, however, may have gone south to Cahokia itseff. For

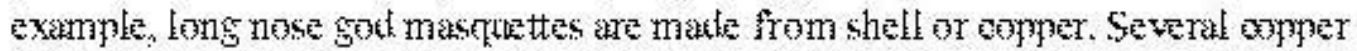
examples eome form the Ameriean Battom, while masquettes mate from shell are fortnd in the periphery. It is ustrally assumed that oopper came from mines arasud the nonthern Great Lakes-either the material or the mastrtettes themselves were trated fom the periphery to the core. If it was the materiat, then the value alated items--the mas quattes themselves-remained in the oore and were not sent baok out to the periphery as we worldk expect if there was an asymmetrieal powier relationship eontroling trate. In the

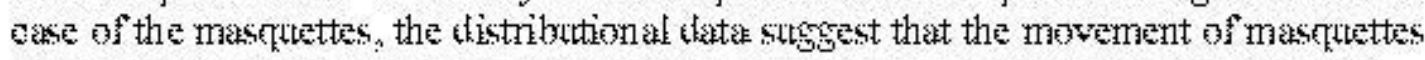

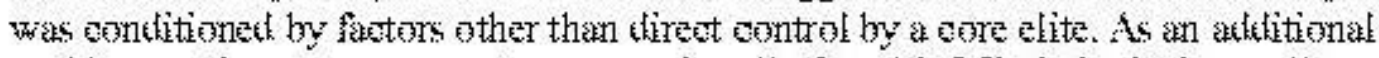
problem, native eopper nrgegets are weasionally formit in Mississigpi River valley Gravels James A. Brown (personal onmmunieation) has surgesested that all of the known 
copper artifacts found at Cahokia could easily have been produced from one large nugget obtained locally and opportunistically. Perhaps of greater importance, copper is not found at Cahokia until after the elaboration of Mississippian social complexity and the major period of growth at the site. If this is the case, it was clearly not the accumulation of copper from the periphery that caused the elaboration, but rather the elaboration of social complexity that allowed access to materials and goods from far-flung localities. It has, in fact, been suggested by Hall (1991) and others that the masquettes were symbols that operated similarly to the historic Calumet pipes used in the Calumet ceremony among Plains Indians. The ceremony was an adoption rite that created fictive kinship relationships between unrelated groups. It can be seen as a way to provide a stable relationship between potentially competitive polities and as a means to provide safe conduct for priests and/or traders who moved between and among polities. In this view, the masquettes were not commodities to be controlled by an elite, but badges of office that facilitated trade in other goods and/or services--quite likely connected with ideologically shared ritual performances.

[Page 13]

Journal of World-Systems Research

Cahokian Ramey Incised pottery, strongly correlated with the presence of exotic shell and copper ornaments, is found at sites throughout the main river drainages of the Midwest, and might be seen as signifying the presence of the economic giant in the core to those in the periphery. Ramey Incised pottery contains decorative elements that historically were powerful symbols of the continuity of life, as well as warrior status (Hall 1991). The falcon or thunderbird motif is present on Cahokia pottery and in stylized form on several peripheral wares such as Oneota and Langford materials throughout the core, semi-periphery, and periphery. Elite ownership and display of Cahokian pottery (or imitations thereof), may be seen as a way for local elites to bolster their own power using support and symbols from the center. A wooden baton, carved into the likeness of a falcon, found in an elite burial at Aztalan may have functioned in this way.

Here again, however, there is a catch. Hall (1991) points out that the distribution of peripheral Oneota ceramics bearing the thunderbird and related motifs matches the distribution of Ramey Incised pottery (Figure 3). If Ramey Incised pottery is an indication that peripheral elites were signalling to their local populations that they were backed by core elites, it is equally possible that the Oneota pottery found at core sites suggests that core elites desired peripheral pottery for similar reasons. The isomorphic distribution of Oneota and Ramey Incised pottery with their ritually important decorative motifs clearly suggests that these items were moving across the Mississippian world via a mechanism free of core elite control. 
Moreover, Ramey Incised pottery is often recovered from general habitation middens, and not necessarily in elite graves or other places of social or ritual significance (Hall 1991). If elites controlled the distribution of these pots, we would expect them to be found clustered in elite house structures and/or graves. The non-clustered depositional context strongly suggests that ownership or trade of Ramey Incised pottery was not under the control of a ruling elite at all. These examples do not support the notion that core elites controlled trade with the peripheral populations. However, it is clear that direct and indirect contact between Cahokia and sites in the far-flung hinterlands was feasible.

We can now look at Stein's third proposition, that a hierarchical systems view requires us to assume that the trade economy transforms the local economy into a dependent supplier of goods to the core. Here we have the most problematic aspect of Mississippian hierarchical core/periphery interaction. As the earlier discussion about meat trade and faunal remains indicated, there is little evidence that Mississippian sites in the Central Illinois, Wabash, or Ohio Rivers were organized to produce any specialized commodities such as bison or deer

[Page 14]

Journal of World-Systems Research

meat (Black 1967; Harn 1975, 1978, 1980). The situation is even worse for Caddoan, Oneota, Fort Ancient, or other Upper Mississippian populations (Brown 1982, 1990; Jeske 1990; Michalik 1982; Rossen 1992). In fact, the opposite appears to be the case. The subsistence economies of Upper Mississippian and Fort Ancient sites demonstrate a very generalized economy with little evidence for multigroup interactions other than raiding.

Where does that leave an investigation into Mississippian core-periphery interactions? It is clear that some exotics such as marine shell did move from the south, through Cahokia to the semi-periphery and periphery. In addition, small amounts of copper and smaller amounts of other exotic items or raw materials possibly moved from the periphery to the core. Moreover, it appears that the movement of these exotics was accompanied by, perhaps aided by, ceramic pots and long-nosed god masquettes symbolizing an ideology revolving around warriors, the continuity of life and the thunderbird. In sum, shell moved from core to periphery, copper from periphery to core (maybe), and symbol-laden ceramics moved in both directions.

If specific 'value-added' items such as shell artifacts were sent from the core to the periphery, but few economic goods or appreciable amounts of preciosities were not sent from periphery to core, then what else might possibly have been returned? Perhaps loyalty and subservience of the peripheral populations. Perhaps local elites were coerced into controlling their populations for the aggrandizement of American Bottom elites. The payoff for the local elites was access to important symbols and political alliances that 
enhanced their own status within their local group. Unfortunately, such loyalty is archaeologically invisible, as Peregrine's (1994) research has demonstrated.

By A.D. 1300, Cahokia itself went into decline while the peripheral Oneota populations expanded. Although the pattern of core decline and periphe ral ascendence is expected in WST, it is difficult to argue that these later Oneota populations ever approximated a true core in terms of social and political complexity that overshadowed surrounding populations. The Oneota world of the 15 th through 17 th centuries did not contain sites with large scale architecture nor did it demonstrate the movement of exotic goods that we use to infer the existence of a ruling elite for Middle Mississippians.

[Page 15]

Journal of World-Systems Research

\section{Summary and Conclusions}

What then can we conclude about taking a world systems approach to Mississippian society? First and foremost, Mississippian society does not seem a compelling case for a hierarchical model of core-periphery interaction. The problems with such a model revolve around four primary areas:

1) The difficulty of boundedness of the core/periphery interactions.

2) The lack of evidence for a highly integrated core for more than a short period within the entire time span of Cahokia's rise and fall.

3) The data necessary to demonstrate elite control of economic resources are not present in the archaeological record.

4) There are insufficient data to suggest that elites controlled access to exotic artifacts and materials in a power-prestige hierarchy that functioned entirely to allow elites to reproduce themselves socially.

However, the notion of differential core-periphery interaction is a framework in which the concepts of gateway communities and prestige-goods exchange can be examined in relationship to each other to find a comprehensive approach to Mississippian society. The task now is to operationalize our expectations for what such a system would look like archaeologically, and to devise testable hypotheses that would differentiate a world systems approach from other concepts such as interaction spheres (Struever and Houart 1972 ) or other models of reciprocal and redistributive trade networks. While this paper has not explored these hypotheses in any detail, future work to refine our expectations for the archacological record and to test these expectations will be forthcoming. 
[Page 16]

Journal of World-Systems Research

\section{References Cited}

Barret, S.

1933 Ancient Aztalan. In Bulletin of the City Museum of the City of Milwaukee, vol. 13. Milwaukee.

Black, G. A.

1967 The Angel Site: An Archaeological, Historical, and Ethnological Study. Indiana Historical Society, Indianapolis.

Breitburg, E.

1992 Vertebrate Faunal Remains. In Fort Ancient Cultural Dynamics in the Middle Ohio Valley, edited by A. G. Henderson, pp. 209-240. Monographs in World Archaeology. vol. 8. Prehistory Press, Madison.

Brown, J. A.

1961 The Zimmerman Site: A Report on Excavations at the Grand Village of the Kaskaskia. Report of Investigations 9. Illinois State Museum, Springfield.

1982 What Kind of Economy Did the Oneota Have? In Oneota Studies, edited by G. E. Gibbon, pp. 107-112. Publications in Anthropology 1. University of Minnesota, Minneapolis.

[Page 17]

Journal of World-Systems Research 
1990 The Oak Forest Site: Investigations into Oneota Subsistence-Settlement in the CalSag Area of Cook County, Illinois. In At the Edge of Prehistory: Huber Phase Archacology in the Chicago Area, edited by J. A. Brown and P. J. O'Brien, pp. 123-308. Center for American Archeology, Kampsville.

Brown, J. A., R. E. Bell and D. G. Wyckoff

1978 Caddoan Settlement Patterns in the Arkansas River Drainage. In Mississippian Settlement Patterns, edited by B. D. Smith, pp. 169-200. Academic Press, New York.

Callender, C.

1978 Miami. In Handbook of North American Indians, edited by B. G. Trigger. No. 15, pp. 681-689. Sinithsonian Institution, Washington.

Chagnon, N.

1988 Life Histories, Blood Revenge, and Warfare in a Tribal Population. Science 239: 985-992.

[Page 18]

Journal of World-Systems Research

Chase-Dunn, C. and T. D. Hall

1991 Conceptualizing Core/Periphery Hierarchies for Comparative Studies. In Core/Periphery Relations in Precapitalist Worlds, edited by C. Chase-Dunn and T. D. Hall, pp. 5-43. Westview Press, Boulder.

Emerson, T. E. and R. B. Lewis (editors)

1991 Cahokia and the Hinterlands. University of Illinois, Urbana. 
Fowler, M. L.

1969 The Cahokia Site: Explorations into Cahokia Archaeology. Bulletin 7. Illinois Archaeology Survey, Urbana.

1978 Cahokia and the American Bottom: Settlement Archaeology. In Mississippian Settlement Patterns, edited by B. D. Smith, pp. 455-478. Academic Press, New York.

Fowler, M. L., and R. L. Hall

1978 Late Prehistory of the Illinois Area. In Northeast, edited by B. G. Trigger, pp. 560568. Handbook of North American Indians vol. 15, W. G. Sturtevant, general editor. Smithsonian Institution, Washington D.C.

[Page 19]

Journal of World-Systems Research

Gibbon, G. E.

1974 A Model of Mississippian Development and its Implication for the Red Wing Area. In Aspects of Upper Great Lakes Anthropology, edited by Eldon Johnson, pp. 129-137. Minnesota Prehistoric Archaeology Series 11, Minnesota Historical Society, St. Paul.

Goldstein, L. G., and J. D. Richards

1991 Ancient Aztalan: The Cultural and Ecological Context of a Late Prehistoric Site in the Midwest. In Cahokia and the Hinterlands, edited by T. E. Emerson and R. B. Lewis, pp. 193-206. University of Illinois, Urbana.

Griffin, J. B. 
1960 A Hypothesis for the Prehistory of the Winnebago. In Culture in History: Essays in Honor of Paul Radin, edited by S. Diamond, pp. 809-865. Columbia University Press, New York.

[Page 20]

Journal of World-Systems Research

Hall, R. L.

1991 Cahokia Identity and Interaction Models of Cahokia Mississippian. In Cahokia and the Hinterlands, edited by T. E. Emerson and R. B. Lewis, pp. 3-34. University of Illinois, Urbana.

Harn, A. D.

1975 Cahokia and the Mississippian Emergence in the Spoon River Area of Illinois.

Transactions of the Illinois State Academy of Sciences 68:414-34.

1978 Mississippian Settlement Patterns in the Central Illinois River Valley. In Mississippian Settlement Patterns, edited by B. D. Smith, pp. 233-268. Academic Press, New York.

1980 The Prehistory of Dickson Mounds: The Dickson Excavation. Illinois State Museum Reports of Investigations No. 35. Springfield.

Hassig, R.

1992 Warfare in Ancient Mesoamerica. Columbia University, New York.

[Page 21]

Journal of World-Systems Research

Hawkes, K. 
1994 Why Hunter-Gatherers Work: An Ancient Version of the Problem of Public Goods. Current Anthropology 34 (4).

Hurley, W. M.

1975 An Analysis of Effigy Mound Complexes in Wisconsin. Anthropological Papers. vol. 59. Museum of Anthropology, University of Michigan, Ann Arbor.

Jeske, R. J.

1990 Langford Tradition Subsistence, Settlement, and Technology. MidContinental Journal of Archaeology 15(2): 221-249.

Keeley, L. H.

1996 War Before Civilization. Oxford University Press, New York and Oxford.

Kelley, J. E.

1991 Cahokia and Its Role as a Gateway Center in Interregional Exchange. In Cahokia and the Hinterlands, edited by T. E. Emerson and R. B. Lewis, pp. 61-82. University of Illinois, Urbana.

[Page 22]

Journal of World-Systems Research

Kuznar, L.

1995 Awatimarka: The Ethnoarchaeology of an Andean Herding Community. Harcou rt Brace, Ft. Worth. 
Langford, G.

1927 The Fisher Mound Group, Successive Aboriginal Occupations Near the Mouth of the Illinois River. American Anthropologist 29: 153-205.

Malinowski, B.

1922 Argonauts of the Western Pacific. Paperback edition, 1961, by Dutton \& Company, New York.

Mehrer, M., and J. M. Collins

1995 Household Archaeology at Cahokia and its Hinterlands. In Mississippian

Communities and Households, edited by J. D. Rogers and B. D. Smith, pp. 32-57.

University of Alabama Press, Tuscaloosa and London.

[Page 23]

Journal of World-Systems Research

Michalik, L. K.

1982 An Ecological Perspective on the Huber Phase Subsistence -Settlement System. In Oneota Studies, edited by G. E. Gibbon, pp. 29-54. Publications in Anthropology 1, University of Minnesota, Minneapolis.

Milner, G. R., E. Anderson, and V. G. Smith

1991 Warfare in Late Prehistoric West-Central Illinois. American Antiquity 56: 581-603.

Parker, K. E. 
1987 Plant Remains. In The Radic Site and the Marcus Site, edited by D. L. McElrath, J. A. Williams, T. O. Maher and M. C. Meinkoth, pp. 221-245. vol. 17. University of Illinois Press, Urbana.

Peregrine, $\mathrm{P}$.

1991 The Evolution of Mississippian Society: A World System Perspective. Prehistory Press, Madison.

[Page 24]

Journal of World-Systems Research

Phillips, P., and J. A. Brown (editors)

1978 Pre-Columbian Shell Engravings from the Craig Mound at Spiro, Oklahoma 1.2 vols. Peabody Museum Press, Cambridge.

Pollack, D. and A. G. Henderson

1992 Toward a Model of Fort Ancient Society. In Fort Ancient Cultural Dynamics in the Middle Ohio Valley, edited by A. G. Henderson, pp. 281-294. Monographs in World Archacology. vol. 8. Prehistory Press, Madison.

Riley, T.

1993 Fly Ash Analysis Supports Emergent Mississippian Agricultural Features at the Lunsford-Pulcher Site (11-S-40) in the American Bottom, Illinois. Plains Anthropologist 38: $177-186$.

Ritzenthaler, R. E., and P. Ritzenthaler 
[Page 25]

Journal of World-Systems Research

1991 The Woodland Indians of the Western Great Lakes. Waveland Press, Prospect

Heights. Originally published in 1983 by Milwaukee Public Museum.

Rogers, J. D.

1995 Dispersed Communities and Integrated Households: A Perspective from Spiro and the Arkansas Basin. In Mississippian Communities and Households, edited by J. D. Rogers and B. D. Smith, pp. 81-98. University of Alabama Press, Tuscaloosa and London.

Rossen, J.

1992 Botanical Remains. In Fort Ancient Cultural Dynamics in the Middle Ohio Valley, edited by A. G. Henderson, pp. 189-208. Monographs in World Archaeology, vol. 8. Prehistory Press, Madison.

Schneider, J.

1991 Was There a Precapitalist World-System? In Core/Periphery Relations in Precapitalist Worlds, edited by C. Chase-Dunn and T. D. Hall, pp. 45-66. Westview Press, Boulder.

[Page 26]

Journal of World-Systems Research

Smith, B.

1978 Variation in Mississippian Settlement Patterns. In Mississippian Settlement Patterns, edited by B. Smith, pp. Academic Press, New York. 
Stein, G.

1993 Power and Distance in the Uruk Mesopotamian Colonial System. Paper presented at the American Anthropological Association Meeting, Washington, DC.

Rosman, A., and P. G. Rubel

1971 Feasting with Mine Enemy: Rank and Exchange among Northwest Coast Societies. Waveland Press, Prospect Heights.

Snow, D.

1995 Iroquois. Columbia University Press, New York.

Strathern, A.

[Page 27]

Journal of World-Systems Research

1971 The Rope of Moka. Cambridge University Press, Cambridge.

Steponaitis, V. P.

1978 Location Theory and Complex Chiefdoms. In Mississippian Settlement Patterns, edited by B. D. Smith, pp. 417-453. Academic Press, New York.

Struever, S. 
1964 The Hopewell Interaction Sphere in Riverine-Western Great Lakes Cultural History. In Hopewellian Studies, edited by J. R. Caldwell, and R. L. Hall, pp. 85-106. Scientific Papers Illinois State Museum, Springfield.

Struever, S., and G. L. Houart

1972 An Analysis of the Hopewell Interaction Sphere. In Social Exchange and Interaction, edited by E. Wilmsen, pp. 5-9. Anthropological Papers 46. Museum of Anthropology, University of Michigan, Ann Arbor.

Sullivan, L. P.

1995 Mississippian Household and Community Organization in Eastern Tennessee. In Mississippian Communities and Households, edited by J. D. Rogers and B. D. Smith, pp. 99-123. University of Alabama Press, Tuscaloosa and London.

[Page 28]

Journal of World-Systems Research

Swanton, J. R.

1946 Indians of the Southeastern United States. Smithsonian Institution Press, Washington, D.C.

Trigger, B.

1990 Huron: Farmers of the North. Holt, Rinehart Winston, New York.

Wallerstein, I.

1974 The Modern World System I. Academic Press, New York. 
Watson, P. J.

1988 Prehistoric Gardening and Agriculture in the Midwest and Midsouth. In Interpretations of Culture Change in the Eastern Woodlands During the Late Woodland Period, edited by R. W. Yerkes, pp. 39-67. Occasional Papers No. 3, Department of Anthropology, Ohio State University, Columbus.

[Page 29]

Journal of World-Systems Research

Yerkes, R.

1985 A Faunal Analysis of the Washington Irving Site. MS on file with author.

[Page 30]

Journal of World-Systems Research 